\title{
CROP INSURANCE: A PATH TO DEVELOPMENT FOR GREEN INDIA
}

\author{
Dr. Vinod Kumar Dave* \\ * Principal and HOD (Accounting), Shree Kheteshwar Mahavidhyalaya, Jodhpur (Raj.)
}

Article DOI: https://doi.org/10.36713/epra7507

DOI No: 10.36713/epra7507

\begin{abstract}
This paper discusses about the crop insurance and its effects on development by green India. It attempts some facts of Indian agriculture and innovation in it through crop insurance; firstly, it discusses about the Indian agriculture its nature and characteristics, secondly, it focuses on crop insurance and rural development of India finally it provide some data of agricultural production enhance in India with introduction of crop insurance. Author depends on some research paper and reports of related study. Literature surveyed by author for identification of crop insurance and its effects on Indian agriculture. The paper aims to provide some suggestion and remedies to development of rural India with better policies of crop insurance.
\end{abstract}

KEY WORDS : Crop Insurance, Green India, Indian Agriculture, Rural India

\section{INDIAN AGRICULTURE : NATURE AND CHARACTERISTICS}

India is an agricultural country, the villagers of India are directly or indirectly dependent on agriculture, cultivates land for livelihood. Many farmers cultivates own land, and then some farmers uses those farmers land who have little human and technical resources to cultivates their own holding of land. The prominent source of income of people living in villages of India is from the produces of their farming, they live their household and social life with the same yield. The excessive part of Indian agriculture land depends on the monsoon, year after year, variation found in monsoon that affected yield of farmers.

Crop insurance is ray of hope for Indian farmers; it is a boon for them. Agriculture insurance assures farmers for a certain amount of income for their crops in a few types of complexities. A wide range of benefits of insurance to insurer resulted to wake up trust in insurance companies to cover their risk regarding crop loss.

\section{RURAL INDIA : MEASURES OF DEVELOPMENT}

Development is blend of numerous belongings with the intention of makes inhabitant life easier and friendly. The development is not visible therefore; every nation measures it on behalf of National Income, Per Capita Income and comparative study over previous year's growth rate. On other hand qualitatively, it measures on health, education, living standards of people and sanitation facility of state. A particular region can be measured it on basis of environmental appropriateness to human life and communications advantage to people. Environmental appropriateness to human life involve fresh air, food and happier environment, and communication of exacting end involve transportation facilities as well as other sources like mobile, internet and postal services.

Faring and forestry is playing significant role in rural development of India for the reason that Indian rural communities are having farming as a prominent occupation. Many agencies that are working for rural development of India have conventionally focused on the utilization of land such as farming and forestry. 
Government of India has a vision of developed rural India on basis of agriculture by using land resources as well as using people inherent talent for agriculture. All agencies and Govt. of India are has focused on wellbeing of human and economic growth of people by farming.

\section{RURAL INDIA : AGRICULTURAL ECONOMY}

Indian agriculture is private and farmers has own land and resources to cultivate his land. Private farming of India move forward farmers to cultivate it with own resources without help of government endeavors. This private agriculture is still depend on monsoon, a petite vary in monsoon volatile yields of farmers. In this scenario, Indian agriculture is high riskoriented and beyond control of farmers efforts. Low and high monsoon has its own limitations but both conditions affect farmers farming badly and farmers suffer huge loss in farming yields. Inverse conditions, flood, license of commercial agriculture and many more formalities of government are other obstacles to Indian farmers.

Indian agriculture is always synonym of hard labor and low income. Farmers' state of affairs becomes dreadful year on year due to lower attentions on a particular policy to agriculture system. The negligence of government, low income and adverse conditions of agriculture dissolved the farmers of India. The migrating of the farmers from the villages to the villages was not new. To flee from the villages of the farmers in the hope of better work, the new chapter was established in the absence of the agriculture income in farming. Although it was not easy for the farmers to migrate from the villages to the cities, but farming nature and attitude forced them to do so. The escape of the farmers was not a mere farmer's family escape; it was like the escape of nature, because the impact on the scenic scenes of cattle and nature was visible from their escape, which used to push back the story of development of villages.
Agricultural development is genuine development of rural India. Before development of agriculture and rural India, government has major challenge to control of migration of farmers. To stop migration government need assure farmers for minimum income from their crop. Agricultural insurance has assured farmers for minimum income, which has encouraged farmers' morale. High morale of the farmers started turning towards the work of farming. Being certified for minimum income, farmers have started using innovative technologies, chemical fertilizers and more yielding methods. Agricultural insurance has assured farmers to bring them back to the fields, while the farmers have started commercial cultivation, thereby increasing their income.

\section{CROP INSURANCE : STORY OF RURAL DEVELOPMENT}

Indian agricultural activities are intrinsically occupied jeopardizes and uncertainties. Risk and uncertainties of agriculture was not competent to farmers pull towards innovative agriculture and employ elevated category technologies to nurture farming and its yield. In presence of this risk-oriented scenario of Indian agriculture, Crop insurance was a boon to reducing the agricultural risks indemnifies the fatalities arising from catastrophic weather. Crop insurance brings security and stability in farmers' income with diversified agriculture on risk protected agriculture (Prakash \& Sharma, 2014). In case of crop loss of any other fatalities farmer acquire ready money from insurance company that enable farmer to avoid selling livelihood assets or obtain loan from Mahazans.

Crop insurance enhances confidence of farmers for inventive cropping by taking more risk on assured reward against crop failure. Farmers' high confidence shifts them in money-making crop growing to a certain extent of customary agriculture of food grains. In most recent few decades commercial agriculture grow in India after launching of crop insurance policy by government of India. 
Table : All India Crop-wise Yield

(Quintal/Hectare)

\begin{tabular}{|l|l|l|l|l|l|l|l|l|l|l|}
\hline Crops & $\mathbf{1 9 5 0 - 5 1}$ & $\mathbf{1 9 9 0 - 9 1}$ & $\mathbf{2 0 0 0 - 0 1}$ & $\mathbf{2 0 1 0 - 1 1}$ & $\mathbf{2 0 1 1 - 1 2}$ & $\mathbf{2 0 1 3 - 1 3}$ & $\mathbf{2 0 1 3 - 1 4}$ & $\mathbf{2 0 1 4 - 1 5}$ & $\mathbf{2 0 1 5 - 1 6}$ & $\mathbf{2 0 1 6 - 1 7 *}$ \\
\hline Rice & 6.68 & 17.40 & 19.01 & 19.01 & 23.93 & 24.61 & 24.16 & 23.91 & 24.00 & 25.50 \\
\hline Jowar & 3.53 & 8.14 & 7.64 & 9.49 & 9.57 & 8.50 & 9.57 & 8.85 & 6.97 & 8.89 \\
\hline Bajra & 2.88 & 6.58 & 6.88 & 10.79 & 11.71 & 11.98 & 11.84 & 12.54 & 11.32 & 13.11 \\
\hline Maize & 5.47 & 15.18 & 18.22 & 25.40 & 24.78 & 25.66 & 26.76 & 26.30 & 25.63 & 26.64 \\
\hline Wheat & 6.63 & 22.81 & 27.08 & 29.88 & 31.77 & 31.17 & 31.45 & 27.50 & 30.34 & 32.16 \\
\hline Cereals & 4.08 & 9.00 & 10.27 & 15.31 & 15.90 & 16.17 & 17.17 & 17.03 & 15.79 & 17.84 \\
\hline Gram & 4.82 & 7.12 & 7.44 & 8.95 & 9.28 & 10.36 & 9.60 & 8.88 & 8.40 & 9.73 \\
\hline Tur & 7.88 & 6.73 & 6.18 & 6.55 & 6.62 & 7.76 & 8.13 & 7.30 & 6.46 & 8.85 \\
\hline Total Pulses & 4.41 & 5.78 & 5.44 & 6.91 & 6.99 & 7.89 & 7.64 & 7.28 & 6.56 & 7.79 \\
\hline $\begin{array}{l}\text { Total Frains } \\
\text { Food }\end{array}$ & 5.22 & 13.80 & 16.26 & 19.30 & 20.78 & 21.29 & 21.20 & 20.28 & 20.42 & 21.53 \\
\hline Sugarcane & 334.22 & 653.95 & 685.78 & 700.91 & 703.17 & 682.54 & 705.22 & 715.12 & 707.22 & 698.86 \\
\hline Groundnuts & 7.75 & 9.04 & 9.77 & 14.11 & 13.05 & 9.95 & 17.64 & 15.52 & 14.65 & 14.24 \\
\hline Mustard & 3.68 & 9.04 & 9.36 & 11.85 & 11.45 & 12.62 & 11.85 & 10.83 & 11.83 & 13.24 \\
\hline Soy Bean & 4.26 & 10.15 & 8.23 & 13.27 & 12.07 & 13.53 & 10.12 & 9.51 & 7.38 & 12.19 \\
\hline Sunflower & 6.53 & 5.35 & 6.05 & 7.01 & 6.92 & 6.55 & 7.50 & 7.36 & 6.08 & 6.99 \\
\hline Total Oilseed & 4.81 & 7.71 & 8.10 & 11.93 & 11.35 & 11.68 & 11.68 & 10.75 & 9.68 & 12.25 \\
\hline Cotton & 0.88 & 2.25 & 1.90 & 4.99 & 4.91 & 4.86 & 5.10 & 4.62 & 4.15 & 5.19 \\
\hline Tobacco & 7.31 & 13.53 & 13.18 & 16.87 & 16.13 & 15.42 & 16.12 & 18.42 & 17.81 & NA \\
\hline
\end{tabular}

NA: Not Available

Source: Directorate of Economics and Statistics, DAC\&FW

\section{LITERATURE REVIEW}

Crop insurance is a tool of minimizing risk of farmers as well as it is tool of risk bearing for innovative and commercial agriculture. Higher innovation and scarification of farmer on behalf of crop insurance increases the production efficiency of farmers (Roberts, 2007). In present time, an insurance company facilitates farmers to choose right crop through index yield of particular region. Agricultural insurance companies are regularly focuses on own returns therefore, insurers are focusing on advanced technologies to reduce risk of crop loss of farmers. Technological advancement and crop awareness programs are organized by insurance companies on time of cropping that reduces risk of farmers and insurers both. After all, Crop insurance reduces vicious circle of loan from mahajans.

Farmers' trust and encouragement from agricultural insurance have resulted in this, as a result of which today agricultural policies have got significant place in national policies. The National Policy on Agriculture that seeking for actualize the vast untapped growth potential of Indian agriculture, strengthen rural infrastructure to support faster agricultural development, promote value addition, accelerate agrobusiness growth, create opportunities for workers, ensure a fair standard of living for farmers and agricultural workers and their families, discourage migration to cities, and meet the challenges faced by economic liberalization and globalization. All these efforts made by the government are directly related to the development of the villages, but the relationship of agricultural insurance is indirect.

Development of agriculture affected employment and wage rate of rural agricultural labor. Rural wages have been rising across worldwide but rates of rural Asia on higher rate, particularly since 2000. Higher rate of labor drive out due to high demand of farm labor as well high efficiency of labor in regard of cropping and harvesting of crop yield. On other hand, Commercial cultivation being expensive, skilled laborers are required, increasing rates of agricultural wages due to requirements of the skilled laborers in farms. Rising wages of rural labor have three important consequences: it reduce poverty by 
setting a floor to low rural incomes; they push up the costs of agricultural production (Wiggins, 2016).

\section{THE STUDY'S OBJECTIVES}

1. To research the evolution of India's crop insurance policy.
2. To assess the current state of the Crop Insurance Scheme and its prospects.

3. To investigate the causes of implementation failures and make recommendations for changes to the Crop Insurance Scheme.

\section{CROP INSURANCE INITIATIVES OR SCHEMES :}

\begin{tabular}{|c|l|l|}
\hline Serial & Year & Initiatives or Schemes \\
\hline 1. & $1972-1978$ & $\begin{array}{l}\text { First individual Approach Scheme } \\
\text { (PCIS) }\end{array}$ \\
\hline 2. & $1979-1984$ & $\begin{array}{l}\text { Comprehensive Crop Insurance } \\
\text { Scheme (CCIS) }\end{array}$ \\
\hline 3. & $1985-1999$ & $\begin{array}{l}\text { National Agricultural Insurance } \\
\text { Scheme (NAIS) }\end{array}$ \\
\hline 4. & $\begin{array}{l}\text { Rabi 1999- 2000 to Rabi } \\
2013-14\end{array}$ & $\begin{array}{l}\text { Modified National Agricultural } \\
\text { Insurance Scheme (MNAIS) }\end{array}$ \\
\hline 5. & $\begin{array}{l}\text { Rabi 2010-11 } \\
\text { season }\end{array}$ & $\begin{array}{l}\text { Weather Based Crop Insurance } \\
\text { Scheme (WBCIS) }\end{array}$ \\
\hline 7 & $2007-08$ & $\begin{array}{l}\text { Coconut Palm Insurance Scheme } \\
\text { (CPIS) }\end{array}$ \\
\hline 8. & 2016 & $\begin{array}{l}\text { Pradhan Mantri Fasal Bima Yojana } \\
\text { (PMFBY) }\end{array}$ \\
\hline
\end{tabular}

\section{CROP INSURANCE HISTORICAL BACKGROUND}

\section{First Individual Approach Scheme (1972- 1978)}

Different kinds of trials on crop insurance on a small, ad-hoc and dispersed scale were begun from 1972-73 when the General Insurance Corporation (GIC) of India launched a Crop Insurance Scheme on $\mathrm{H}-4$ cotton and subsequently added groundnut, wheat and potato. Andhra Pradesh, Gujarat, Karnataka, Maharashtra, Tamil Nadu, and West Bengal were among the states to implement the scheme. It lasted up to 1978-79 and insured just 3,110 farmers for a premium of Rs.4.54 lakh against claims of Rs.37.88 lakh.

\section{Pilot Crop Insurance Scheme (PCIS) (1979- 1984)}

The Pilot Crop Insurance Scheme was established by the GIC in 1979, which was based on the 'Area Approach' for providing insurance protection against a shortfall in crop production below the threshold level. The Scheme included cereals, millets, oilseeds, cotton, potato and chickpea and it was limited to loanee farmers of institutional sources on a voluntary basis. The PCIS 1979 was implemented in 12 states until 1984-85 and covered 6.23 lakh farmers for a premium of Rs.195.01 lakh against claims of Rs. 155.68 lakh over the whole time.

\section{Comprehensive Crop Insurance Scheme (CCIS) (1985-99)}

The Comprehensive Crop Insurance Scheme (CCIS) established in 1985 was the first nation-wide Scheme. Previous Schemes were either experimental or Pilot Projects, on a limited size and in a dispersed way. This program was connected to short-term financing and was based on the homogenous area approach'. The Central Government launched the CCIS during the year 1985-86. Till Kharif 1999, the Scheme was approved by 15 States and 2 Union Territories (UTs) (UTs). Both, PCIS and CCIS were limited exclusively to farmers who had received seasonal agricultural loans from banking organizations. The major difference between PCIS and CCIS was that PCIS was on voluntary basis while CCIS was obligatory for loanee farmers. The CCIS insured 763 lakh farmers for a premium of Rs.404 crore against claims of Rs.2303 crore. A more comprehensive Scheme, 'National Agricultural 
Insurance Scheme was established in 1999 with objective to insure all farmers irrespective of loanee or non-loanee.

\section{National Agricultural Insurance Scheme (NAIS)}

The National Agricultural Insurance Scheme (NAIS), with the goal to improve coverage of farmers, crops and risk commitment, was implemented in the nation from Rabi 1999-2000 replacing the previous Comprehensive Crop Insurance Scheme (CCIS). The primary aim of the Scheme was to safeguard the farmers from the agricultural losses experienced on account of natural catastrophes, such as, drought, flood, hailstorm, cyclone, pests and diseases. The Scheme was executed by the Agriculture Insurance Company of India Ltd. (AIC).

The Scheme was accessible to all the farmers both loanee and non-loanee irrespective of their amount of property. It envisages coverage of all the food crops (cereals, millets and pulses), oilseeds and annual commercial/horticultural crops, in respect of which historical yield data is available for sufficient number of years. The Scheme was extended until Kharif 2013, however, certain States are permitted to utilize NAIS during Rabi 2013-14 as well.

The Scheme was optional for States/Union Territories (UTs) and it had been adopted by the 25 States and 2 Union Territories in one or more seasons. Since the commencement of the Scheme 2084.78 lakh farmers for a premium of Rs.8,67,121 lakh against the claim of Rs.25,37,558 lakh were covered till 2012-13. The total area insured was Rs.3137.70 lakh hectares over the same time.

\section{Modified National Agricultural Insurance Scheme (MNAIS)}

To enhance further and make the Scheme simpler and more farmer friendly, a proposal on Modified National Agricultural Insurance Scheme (MNAIS) was created and was accepted by Government of India for implementation on trial basis in 50 districts from Rabi 2010-11 season.

During the Five seasons of its implementation in 17 States, the MNAIS insured 45.80 lakh farmers for a premium of Rs.1,08,800 lakh against the claim of Rs.86,400 lakh till Rabi 2012-13. The total area insured was 46.79 lakh hectares over the same time.

\section{Pilot Weather Based Crop Insurance Scheme (WBCIS) :}

With the aim to bring more farmers into the fold of Crop Insurance, a Pilot Weather Based Crop Insurance Scheme (WBCIS) was established in 20 States in 2007. Apart from Agriculture Insurance Company of India, several private firms have also been authorized to execute the Scheme. The WBCIS is designed to offer insurance protection to the farmers against unfavorable weather occurrences, such as deficiency and excess rainfall, high or low temperature, humidity etc. which are considered to affect negatively the agricultural output. It has the benefit to resolve the disputes within shortest feasible period. The WBCIS is based on actuarial rates of premium but to make the Scheme appealing, premium actually levied from farmers has been limited at par with NAIS.

The WBCIS was implemented in 18 States and 469.38 lakh farmers were insured for a premium of Rs.7,51,920 lakh against the claims of Rs. 52,860 lakh under the Scheme from 2007-08 to 2012-13. The total area insured was 632.01 lakh hectares over the same time.

\section{Pilot Coconut Palm Insurance Scheme (CPIS)}

The Coconut Palm Insurance Scheme (CPIS) was authorized for implementation on pilot basis for the years 2009-10 and 2010-11 in the chosen regions of Andhra Pradesh, Goa, Karnataka, Kerala, Maharashtra, Odisha and Tamil Nadu. Later on, it was expanded to West Bengal too. The pilot was executed during the years 2011-12 and 2012-13 and continues to be under execution during the year 2013-14 aswell. Fifty percent of the premium is provided by Government of India, 25 percent by the relevant State Government and the remaining 25 percent by the farmer. The CPIS is managed by the Coconut Development Board (CDB). Under the Scheme, 51,108 farmers were insured for a premium of Rs.167.69 lakh against the claims paid of Rs.214.05 lakh until December 2013. And the total area covered over the same time was 25,938 hectares.

\section{National Crop Insurance Programme (NCIP)}

To make the Crop Insurance Schemes more farmer friendly, a restructured Central Sector Scheme in the name of 'National Crop Insurance Programme' (NCIP) was launched from Rabi 2013-14. The previous MNAIS, WBCIS and CPIS were combined under this project with numerous upgrades and adjustments for adoption across the nation. However, 
on the basis of petitions submitted, certain States have been permitted to adopt NAIS during Rabi 2013-14.

The coverage of NCIP in terms of farmers and area insured has been predicted to the level of 50 percent each from the current level of approximately 25 percent and 20 percent respectively by the terminal year 2016-17 of the Twelfth Plan. The coverage under CPIS is anticipated at 25 percent of coconut farmers during 2013-14 with growth of 5 percent each year throughout remaining years of Twelfth Five Year Plan.

\section{ADVANTAGE OF CROP INSURANCE IN DEVELOPMENT}

Crop insurance has given a new hope to the farmer. India's agriculture has always been considered a 'monsoon gamble'. Whenever the farmer sowed the crop, his mind was worried about the damage caused by natural and other calamities. But in the present time crop insurance has become a special tool for him, so that he can reduce his chances of loss to a great extent. The farmer can insure his potential losses up to a limit in return by paying a nominal amount. With the assurance of compensation by the insurance company for his possible losses, the farmer has started doing more risky farming in place of traditional farming.

Risky farming refers to such farming which is to be done commercially with the help of modern equipment instead of having traditional methods and grain products. The assurance of the insurance company is proving to be a boon for him behind the cultivation of commercial and fruit orchards. In particular, the number of trees and gardens is increasing rapidly in rural areas of India due to the planting of fruit orchards. The farmers of India have now started cultivating more than once, in such a situation that more water is being given artificially in the fields. Today even in desert areas like Rajasthan, clumps of trees have started appearing on the bunds of the fields.

With the assurance of insurance, where the farmer has started doing commercial farming, then keeping in mind the shade in the fields, he has started planting trees in sufficient quantity on the bund. In such a situation, plantation has started rapidly in the rural areas of India. Greenery is also increasing due to rapid plantation. In Israel, the deterioration of agricultural incomes in the last two decades has been perhaps more extreme than in other countries, as a result of a sharp decline in government support and protection (Kislev
\& Yoav, 1992). In comparison of international scenario Indian government helping farmer so, it is a great hope for us development as well green India.

\section{PROBLEMS CONNECTED TO CROP INSURANCE}

Agriculture is the primary pillar of the Indian economy it forms the backbone of rural livelihood security system. Agriculture in India is diverse, diversified and prone to a range of hazards. It is the core planned economic development in India since the trickledown effect of agriculture is important in the decreasing poverty and regional inequalities in the nation. Most farmers are tiny and marginal ones. In most regions, agriculture is rain fed, leading to a higher degree of production unpredictability and risk.

Growth in agriculture has a maximum cascade effect on other sectors leading to distribution of growth, equality and benefits across the whole economy. The entire geographical area of the nation is 328.7 million hectares of which 141 million hectares is the net sown area, 190 million hectares is the gross cropped area. The agricultural industry represents approximately 20 per cent of the GDP and gives employment to 58 per cent of the workers.

Crop Insurance, which aimed at tackling yield risk - though essential for a large majority of farmersis susceptible to structural, design and financial issues. Problems of asymmetry of information-moral hazard and adverse selection-and co-variability are more apparent in crop insurance than in other types of insurance. Consequently, crop insurance systems confront numerous difficulties. In response to such issues, Schemes based on the area concept were developed in the 1980s. More modern Insurance Schemes are based on weather, and use an area approach. Due to the breadth of the nation, huge number of small and marginal farmers, and adoption of area-based methods, many agencies and organizations are engaged in crop insurance schemes.

Hence, coordinated efforts are essential for successful implementation of crop insurance program. There are numerous flaws in the execution of the Crop Insurance Schemes. The numerous problems connected to Crop Insurance such as:-

- Paucity of the financial resources of the State Government.

- Regular occurrence and intensity of natural disasters.

- Unreliable estimate regarding crop damages.

- Improper Land records. 
- Growing sub-division and fragmentation of land ownership.

- $\quad$ Abject economic destitution of the small and marginal farmers.

- Illiteracy and stupidity of the farmers.

- Lack of co-ordination between Govt. With various insurance organizations.

- Discrepancy in area insured.

- Delay in getting crop - cutting data and quality and dependability of such data.

- Weather data.

- Crop loan practices.

- Crop insurance premium.

- Settlement of Claims.

- Role of Banks and Agricultural Insurance Companies in the functioning of programs and

- Awareness of farmers about different aspects of the Schemes.

\section{A STEP AHEAD}

In the last few years, there has been rapid progress of greenery in rural areas of India. Along with the production of crops, there has also been progress in the production of fruits, which is a proof of growing trees. Apart from all these things, there is still a lack of complete knowledge of scientific changes in agriculture and mechanical equipment in many areas. The lack of schemes by the government to encourage farmers to plant trees in addition to insurance is still a major obstacle in the entire Green India.

Nevertheless, experts are hopeful that in the coming years there will be a progressive increase in the number of trees in rural areas of India. Indian farmers are trying to earn extra income by cultivating fruits and cultivating timber along with traditional farming. Today, farmers are trying to increase their income, in such a situation, planting tall trees on their agricultural land; they can cultivate vegetables and small plants below. At the same time, keeping in mind the need of shade in the fields for the scientific thinking of the farmers and also for the cultivation of cold climate, progressive progress in the number of trees in the fields is abound in the near future.

Promotion of agricultural productivity by competitive activities. Investment in agriculture fishing, forestry, irrigation and drainage, agricultural trade, and agribusiness - has increased significantly (Worlds Bank, 2007). With extent of agriculture an agriculture economy based country like India economy increase on higher growth rate with development of subsidiary activities.

\section{SUGGESTIONS AND REMEDIES}

After the introduction of crop insurance, there has been a gradual progress in the production of crops in India. The number of trees has also increased in rural India. Today the Government of India is trying to double the income of the farmers, so efforts should be made to promote the cultivation of fruits along with traditional crops. Efforts should be made to promote more than one crop (fruits and cereals) in the same field at a time. With such a step of the Government of India, it is possible to increase the income of the farmers as well as the development of rural India.

A web gateway should be established for all States to allow land record data be accessible to financial institutions. Premium rates to be reviewed for MNAIS. Reserve Bank of India (RBI) and National Bank for Agriculture \& Rural Development (NABARD) should properly monitor the compliance of their circulars on obligatory crop insurance for loanee farmers.Insurance firms and banks should play a proactive role in ensuring efficient execution of crop insurance programs.State Governments should guarantee the usage of GPRS-enabled and camera equipped mobile phones etc. when undertaking crop cutting trials. An Atlas of key weather components for various agro-climatic areas and An Agricultural Insurance Act should be developed to take account of particular requirements of the crop insurance and agricultural insurance in general.

For the development of rural India, such efforts should be made by the government so that where farmers are interested in farming on one hand and on the other hand they are encouraged to do farming through scientific methods. By doing this, there is bound to be an increase in the income of the farmers. The Government of India should provide assurance to the farmers to get income from insurance to a certain extent in addition to financially supporting them. Include all those facts in the insurance, due to which there is a possibility of loss to the farmer and help centers should be opened in rural areas to give them the right advice.

\section{CONCLUSIONS}

Crop insurance has awakened the interest of farmers to do farming through scientific methods and get more income. Today the increasing agricultural production is the result of the government's crop insurance policies. Especially in rural India, increasing greenery is the result of the advanced policies of today's government, but the failure of the government 
to achieve international level in the income of farmers. The government is trying to increase the income of the farmers, it can be seen clearly. To encourage the farmers, the government is also giving money directly to the farmers in various ways, so that the farmers can have a positive attitude towards farming and rural India can develop.

Crop insurance has not only increased the production of food grains, it has also increased commercial and fruit cultivation. If the government changes some policies and encourages the farmers to do more than one farming at a time (cultivation of high trees and low food grains), then in the coming days there seems to be a strong possibility of full development of India's overall development from Green India.

\section{REFERENCES}

- Jodha, N.S. (1981). Role of Credit in Farmers" Adjustment Against Risk in Arid and Semi-Arid Tropical Areas of India. Economic and Political Weekly. XVI (22\&23).

- Kislev, \& Yoav. (1992). problems connected to Crop Insurance Family Farms, Cooperatives and Collectives. Aldershot, England: Dartmouth: G.H. Peters and B.F. Stanton.

- Mishra, P.K. (1994) : Crop Insurance and Crop Credit : Impact of the Comprehensive Crop Insurance Scheme on Cooperative Credit in Gujarat. Journal of International Development. 6(5) : 529-68.

- Bhende, M.J.(2002). An analysis of Crop Insurance Scheme in Karnataka. Bangalore: Agricultural Development and Rural Transformation Unit, Institute for Social and Economic Change (ISEC).

- Jain, RCA (2004): Challenges in Implementing Agriculture Insurance and Re-insurance in Developing Countries, The Journal, January-June, pp $14-23$.

- Bank, W. (2007 ). Agriculture and Rural Development. World Bank Issue Brief .

- Agricultural Statistics at a Glance (2007): Agricultural Statistics Division, Department of Agriculture and Co-operation, Ministry of Agriculture, GOI, New Delhi.

- Roberts, M. J., O'Donoghue, E., \& Key, a. N. (2007). Does Crop Insurance Affect Crop Yields? Annual Meeting of the AAEA,, (pp. 1-18). Portland, Oregon.

- Prakash, R., \& Sharma, R. (2014). Appraisal and Future of Crop Insurance Schemes in India with Special Reference of NAIS. 86-92.

- Wiggins, S. (2016). Agricultural and rural development reconsidered A guide to issues and debates. IFAD. 